\title{
ANALISIS ARSITEKTUR TEKNOLOGI INFORMASI \\ PADA SMK NEGERI 1 MAJALENGKA MENGGUNAKAN FRAMEWORK TOGAF
}

\author{
Tantri Wahyuni ${ }^{1}$, Sandi Fajar Rodiansyah ${ }^{2}$, Amin Aris Munandar ${ }^{3}$ \\ ${ }^{1,23}$ Alamat: Jl. Universitas Majalengka No.1 Majalengka 45413 Indonesia
}

\begin{abstract}
Abstrak
SMK Negeri 1 Majalengka merupakan Sekolah Menengah Kejuruan negeri yang cukup besar di wilayah Kabupaten Majalengka, namun teknologi informasinya masih kurang efisien karena belum semua terintegrasi ke sistem, kurangnya aplikasi pendukung untuk menunjang sistem informasi dan adanya permasalahan pada jaringan. Solusi untuk mengatasi hal ini adalah dibuatkannya beberapa aplikasi untuk menunjang keefisienan sistem informasi dan dari beberapa aplikasi tersebut diintegrasikan ke sistem informasi SMKN 1 Majalengka,. Penerapan arsitektur tersebut bertujuan untuk menciptakan keselarasan antara proses bisnis dan sistem informasi. Untuk membuat perancangan arsitektur sistem informasi membutuhkan suatu framework yang lengkap dan mudah untuk digunakan. TOGAF ADM(The Open Group Architecture Framework Architecture Development Method) merupakan metodologi yang lengkap serta mudah untuk digunakan dalam pembuatan arsitektur sistem informasi ini karena tahapannya yang jelas dan terstruktur. Tahapan perancangan arsitektur ini bertujuan untuk merencanakan implementasi sistem informasi. Keluaran yang dihasilkan sebagai acuan dalam pengembangan sistem informasi untuk mencapai tujuan yang diharapkan.
\end{abstract}

Kata kunci: Framework, TOGAF, Arsitektur, SMKN 1 Majalengka

\begin{abstract}
SMK Negeri 1 Majalengka a vocational High School land fairly sizeable in the district of Majalengka, but information technology is still less efficient of which have all integrated into the system, lack of supporting application to support the efficiency of information systems, there are still problems on the network. The solution to overcome this problem is make several application to support the efficiency of information systems and of these application are integrated into the information system SMK 1 Majalengka, on the network needs to be replace a few device that have outdate replaced with the more recently thus making the user who use the facilities internet becomes comfortable and unhindered. The implementation of the architecture aims to create harmony between business process and information systems. To make the design of information systems architecture requires a framework that is complete and easy to use. TOGAF ADM is a complete methodology and easy to use in the making of this information systems architecture for a clear and structured stages. The aim of this architectural design stage to plan the implementation of information systems in the future. The output generated as a reference in the construction and development of information systems in an organization to achieve the desired objectives.
\end{abstract}

Keywords: Framewotk, Togaf, Architercture, SMKN 1 Majalengka 


\section{PENDAHULUAN}

Pada saat ini, Teknologi Informasi tidak hanya diharapkan sebagai perangkat pembantu kegiatan organisasi tetapi sudah merupakan strategi dari suatu organisasi untuk mencapai tujuannya. Namun yang jadi masalah saat ini adalah bagaimana menyelaraskan antara strategi bisnis dan strategi teknologi. Terdapat berbagai macam pengertian sistem informasi menurut beberapa ahli, diantaranya sebagai berikut, sistem informasi adalah suatu sistem didalam suatu organisasi yang mempertemukan kebutuhan pengolahan transaksi harian yang mendukung fungsi operasi organisasi yang bersifat manajerial dengan kegiatan strategi dari suatu organisasi untuk dapat menyediakan kepada pihak luar tertentu dengan laporan-laporan yang diperlukan. (Sutabri, 2012). Sistem informasi didefinisikan sebagai suatu sistem yang dibuat oleh manusia yang terdiri dari komponen-komponen dalam sebuah organisasi untuk menyajikan informasi yang tepat dan akurat. (Yakub, 2012). Dari beberapa pendapat di atas dapat disimpulkan bahwa sistem informasi merupakan gabungan dari manusia, hardware, software, jaringan komunikasi dan data yang saling berinteraksi untuk menyimpan, mengumpulkan, memproses, dan mendistribusikan informasi untuk mendukung pengambilan keputusan dalam suatu organisasi. Sistem informasi merupakan aset yang sangat penting bagi suatu organisasi atau perusahaan saat ini. Perusahaan yang melakukan perencanaan dan pengelolaan sistem informasi dengan baik,proses bisnis perusahaan/organisasi tersebut akan berjalan dengan lancar. Oleh karena itu, organisasi atau perusahaan memerlukan perencanaan strategis sistem informasi yang tepat. Salah satu organisasi atau perusahaan yang memanfaatkan perkembangan Teknologi Informasi saat ini adalah SMK Negeri 1 Majalengka.

Menurut Tanenbaum (2000), Jaringan Komputer merupakan kumpulan dari perangkat keras dan lunak di dalam suatu sistem yang memiliki aturan tertentu untuk mengatur seluruh anggotanya dalam melakukan aktivitas komunikasi. Satu komputer yang terkoneksi ke jaringan menjadi satu node dari jaringan tersebut. Sedangkan host secara umum diartikan sebagai komputer yang terkoneksi ke jaringan yang dapat memberikan layanan jaringan (network service). Dari pengertian jaringan komputer diatas, dapat disimpulkan bahwa Jaringan komputer adalah sebuah kumpulan komputer, printer dan peralatan lainnya yang terhubung. Informasi dan data bergerak melalui kabel-kabel sehingga memungkinkan pengguna jaringan komputer dapat saling bertukar dokumen dan data, mencetak pada printer yang sama dan bersama sama menggunakan hardware dan software yang terhubung dengan jaringan. Salah satu metode yang dapat digunakan dalam menganalisa sebuah arsitektur jaringan yaitu menggunakan metode framework Togaf (The Open Group Architecture Framework). Togaf framework adalah sebuah enterprise architecture framework yang memberikan pendekatan komprehensif untuk merancang, merencanakan, melaksanakan, dan mengelola. Togaf framework juga memiliki ADM (Architecture Development Method) yang merupakan metodologi yang terdiri dari beberapa tahapan untuk mengembangkan dan memelihara technical architecture dari organisasi. Menurut beberapa referensi yang digunakan, framework togaf dipilih pada kasus ini karena konsepnya yang memiliki pendekatan komprehensif untuk merancang, merencanakan, melaksanakan, dan mengelola, sehingga fokus pada semua unsur perusahaan, termasuk proses bisnis yang ada. Oleh karena itu, perlu adanya "Analisis dan Perencanaan Arsitektur Teknologi Informasi Pada SMK Negeri 1 Majalengka Menggunakan Metode FrameworkTogaf".Adapun rumusan masalah berdasarkan identifikasi masalah di atas yaitu: 1 Bagaimana membuat perencanaan arsitektur enterprise dengan menggunakan framework TOGAF. 2 Bagaimana suatu jaringan yang tersebar disetiap unit yang ada di SMK Negeri 1 Majalengka dapat terintegrasi sehingga tidak membutuhkan waktu yang lama untuk dapat mengaksesnya. Adapun 
tujuan dari penelitian ini adalah: 1. Menghasilkan perencanaan arsitektur enterprise yang meliputi arsitektur bisnis, data, aplikasi, dan teknologi guna mendukung aktifitas bisnis utama di SMK Negeri 1 Majalengka; 2. Membuat sebuah jaringan yang terintegrasi dari semua unit yang ada di SMK NEgeri 1 Majalengka. Manfaat yang diharapkan dari penelitian ini dapat berguna bagi SMK Negeri 1 Majalengka dalam pengembangan sistem informasi yang lebih baik dan lebih terintegrasi

\section{PENELITIAN TERKAIT}

Pada penelitian ini ada penelitian lain yang dijadikan landasan dalam melaksanakan penelitian. Berikut ada dua penelitian terkait:

Tabel 1. Penelitian Terkait

\begin{tabular}{|c|c|c|c|}
\hline $\begin{array}{c}\text { Penelitin } \\
\text { (Tahun) }\end{array}$ & $\begin{array}{l}\text { Variabel } \\
\text { Penelitian }\end{array}$ & $\begin{array}{l}\text { Metode } \\
\text { Analisis }\end{array}$ & Kesimpulan \\
\hline $\begin{array}{l}\text { Edi Suya Negara } \\
\text { dan Yanti Febri } \\
(2016)\end{array}$ & $\begin{array}{l}\text { Arsitektur } \\
\text { teknologi }\end{array}$ & $\begin{array}{l}\text { TOGAF } \\
\text { Architecture } \\
\text { Development } \\
\text { Method }\end{array}$ & $\begin{array}{l}\text { Analisis dan perancangan arsitektur } \\
\text { teknologi informasi berbasis cloud } \\
\text { computing akan diterapakan bagi } \\
\text { seluruh universitas di Sumatera } \\
\text { Selatan, untuk menyamakan standar } \\
\text { pengembangan teknologi informasi } \\
\text { di masing masing universitas. } \\
\text { Sehingga dengan adanya } \\
\text { standarisasi arsitektur teknlogi } \\
\text { informasi ini akan memberikan } \\
\text { dampak yang signifikan dalam } \\
\text { meningkatkan mutu dan kualitas } \\
\text { perguruan tinggi di Sumatera } \\
\text { Selatan untuk mewujudkan insan } \\
\text { Indonesia cerdas dan kompetitif. } \\
\text { Tahap pertama untuk proses } \\
\text { analisis dilakukan dengan } \\
\text { mengumpulkan data dari masing } \\
\text { masing universitas yang ada di } \\
\text { Sumatera Selatan dengan metode } \\
\text { survei dan observasi. Selanjutnya } \\
\text { dari data tersebut akan diolah } \\
\text { sehingga menghasilkan sebuah } \\
\text { rancangan arsitektur teknologi } \\
\text { informasi berbasis cloud computing }\end{array}$ \\
\hline $\begin{array}{l}\text { Nurma } \\
\text { Harumiaty, Eva } \\
\text { Hariyanti dan } \\
\text { Taufik (2013) }\end{array}$ & $\begin{array}{l}\text { Arsitektur } \\
\text { teknologi, } \\
\text { perencanaan } \\
\text { arsitektur, } \\
\text { peluang dan } \\
\text { solusi }\end{array}$ & $\begin{array}{l}\text { TOGAF } \\
\text { Architecture } \\
\text { Development } \\
\text { Method }\end{array}$ & $\begin{array}{l}\text { Perpustakaan Universitas Airlangga } \\
\text { perlu membuat perencanaan } \\
\text { arsitektur teknologi yang baru } \\
\text { dengan } \\
\text { menggunakan kerangka kerja yang } \\
\text { sesuai yaitu TOGAF (The Open } \\
\text { Group Architecture Framework) } \\
\text { ADM Development } \\
\text { (Architecture } \\
\text { Method) yang merupakan inti dari } \\
\text { TOGAF. Tujuannya untuk } \\
\text { menyelaraskan strategi } \\
\text { bisnis perpustakaan dengan strategi } \\
\text { teknologi untuk memberikan hasil }\end{array}$ \\
\hline
\end{tabular}




\begin{tabular}{|c|c|c|c|}
\hline & & & $\begin{array}{l}\text { yang optimal bagi perpustakaan. } \\
\text { Pada } \\
\text { laporan penelitian ini tahapan yang } \\
\text { harus dilakukan pada TOGAF } \\
\text { ADM, antara lain: fase persiapan, } \\
\text { visi arsitekur, } \\
\text { arsitektur teknologi, serta peluang } \\
\text { dan solusi. Pada akhir tahap } \\
\text { perencanaan arsitektur, diuraikan } \\
\text { analisis gap serta } \\
\text { strategi implementasinya. Setelah } \\
\text { dilakukan tahapan-tahapan TOGAF } \\
\text { ADM pada akhirnya akan terlihat } \\
\text { gap antara kondisi sekarang dengan } \\
\text { penggunaan arsitektur pada masa } \\
\text { mendatang. Pada komponen } \\
\text { hardware 62,5\% dipertahankan dan } \\
37,5 \% \text { a } \\
\text { mengalami pergantian agar } \\
\text { hardware berjalan lebih optimal. } \\
\text { Komponen software } 38,47 \% \\
\text { dipertahankan } \\
\text { mengalami pergantian dengan } \\
\text { meng-upgrade software serta } \\
\text { menambah beberapa fitur aplikasi } \\
\text { yang dibutuhkan kedalam aplikasi } \\
\text { LARIS (Library Automation } \\
\text { Retrieval Information System) dan } \\
\text { 15,38\% menambah komponen baru. } \\
\text { Komponen network } 87,5 \% \\
\text { dipertahankan dan } \\
\text { mengalami pergantian LAN } \\
\text { menjadi Virtual LAN yaitu network } \\
\text { dapat dikonfigurasi secara virtual } \\
\text { tanpa harus menuruti lokasi fisik } \\
\text { peralatan sehingga penggunaan } \\
\text { VLAN akan membuat pengaturan } \\
\text { jaringan menjadi sangat fleksibel. }\end{array}$ \\
\hline $\begin{array}{l}\text { Atina Dwi } \\
\text { Palupi (2006) }\end{array}$ & $\begin{array}{l}\text { Rancangan } \\
\text { Arsitektur } \\
\text { Teknologi }\end{array}$ & Togaf ADM & 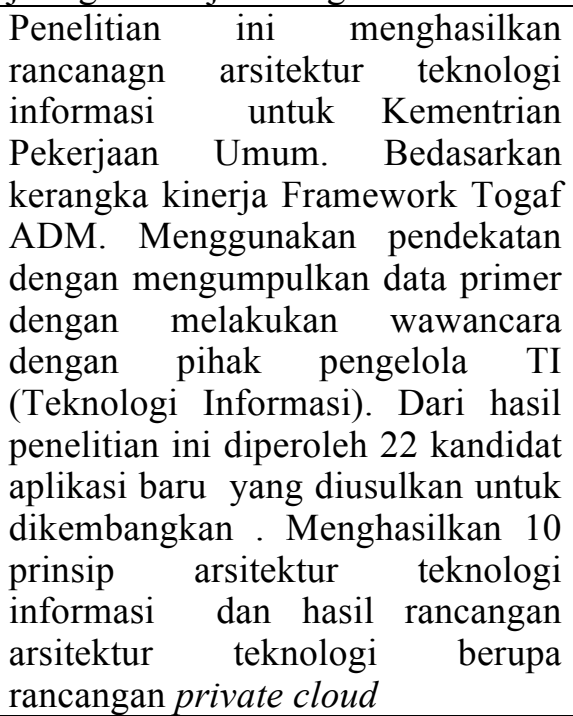 \\
\hline
\end{tabular}




\section{METODE PENELITIAN}

Berikut adalah tahapan penelitian yang dilakukan di lembaga pendidikan SMK Negeri 1 Majalengka :

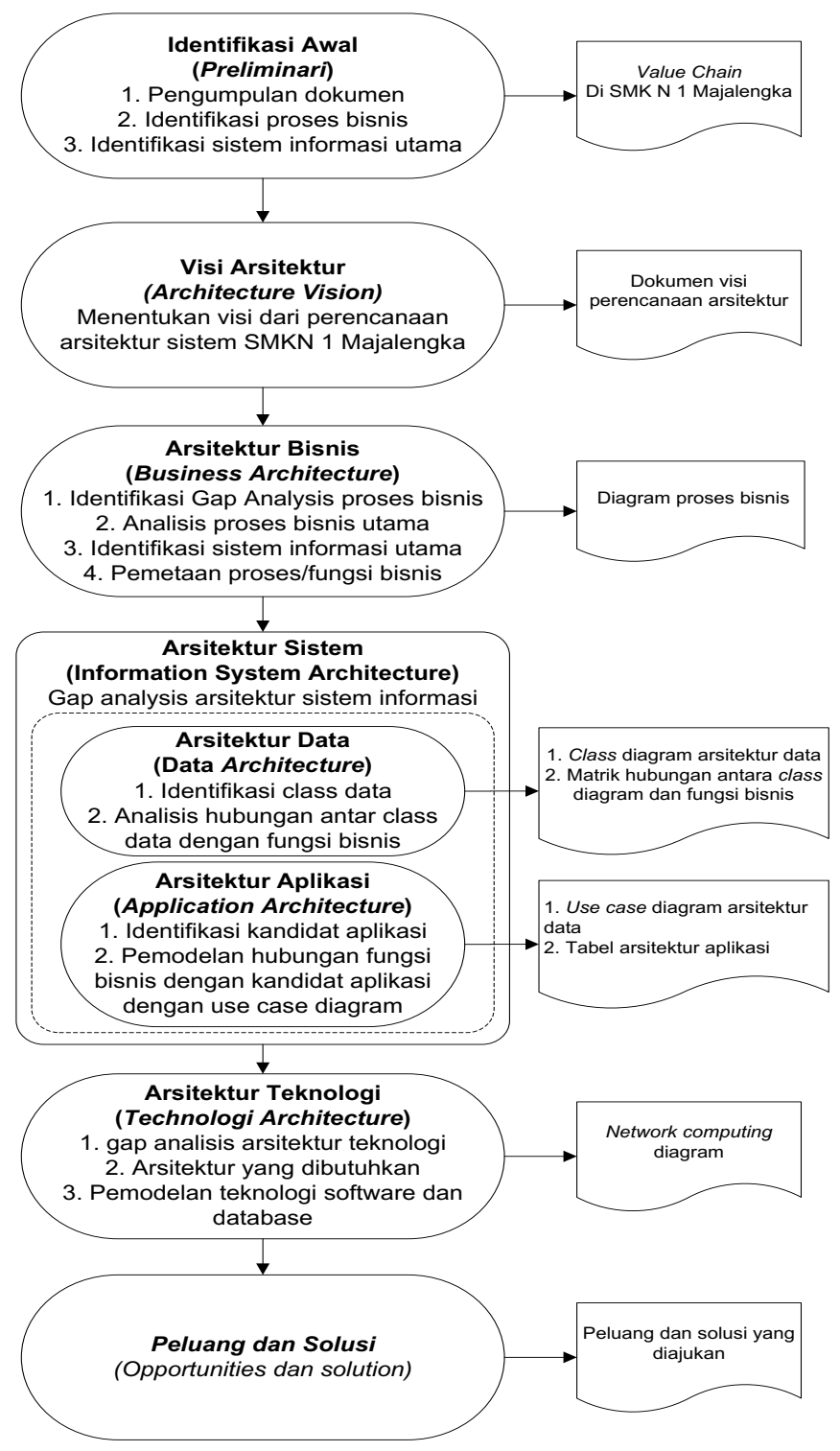

Keterangan Gambar:

Gambar 1 Tahapan Penelitian

1. Identifikasi Awal

Tahapan ini dilakukan untuk mengidentifikasi komponen-komponen yang terkait penelitian dengan melakukan observasi dan studi dokumen yang digunakan dalam proses kegiatan yang berhubungan dengan sistem dilingkungan SMK Negeri 1 Majalengka. Langkahlangkah dalam tahapan ini meliputi:

- Pengumpulan data-data atau eksplorasi dokumen-dokumen terkait strategi organisasi, visi dan misi, tujuan kebijakan yang diterapkan dan struktur organisasi di SMK Negeri 1 Majalengka; 
- Melakukan identifikasi proses-proses bisnis yang terkait dengan sistem utama pada SMK Negeri 1 Majalengka dan memetakannya dengan value chain. Pada tahapan ini akan menghasilkan value chain dari organisasi yang akan dijadikan parameter dan batasan dalam perencanaan sistem ada pada penelitian ini.

\section{Visi Arsitektur}

Pada tahapan ini dibahas mengenai visi dari perancangan arsitektur pada SMK Negeri 1 Majalengka yang dilakukan guna mendukung aktifitas bisnis sesuai dengan visi dan misi dari organisasi. Hasil dari tahapan ini berupa dokumen visi dari perencanaan arsitektur sistem pada SMK Negeri 1 Majalengka yang berasal dari keinginan stakeholder dan akan menjadi acuan pada proses tahapan perencanaan arsitektur pada SMK Negeri 1 Majalengka ini.

\section{Arsitektur Bisnis}

Pada tahapan ini dilakukan analisis terhadap proses bisnis yang sedang berlangsung saat ini. Adapun langkah-langkah yang dilakukan pada tahapan ini meliputi:

- Membuat gap analysis proses bisnis berupa analisis kesenjangan pada kondisi saat ini, dan diajukan analisis penyelesaian dan target penyelesaian dalam jangka panjang;

- Melakukan analisis terhadap proses-proses bisnis di SMK Negeri 1 Majalengka, dan memetakannya dalam tabel Business Process Working Sheet selanjutnya alur prosesnya dimodelkan dengan menggunakan BPMN( Businesss Process Model and Notation) diagram untuk proses-proses yang terkait dengan kegiatan di SMK Negeri 1 Majalengka;

- Melakukan analisis hubungan antara proses/fungsi bisnis yang telah teridentifikasi sebelumnya dengan unit organisasi dengan menggunakan fungsi matriks bisnis.

\section{Arsitektur Sistem}

Pada tahapan ini dilakukan pemodelan arsitektur sistem informasi yang akan dirancang sesuai dengan hasil sebelumnya, meliputi pemodelan arsitektur data dan pemodelan arsitektur aplikasi, akan tetapi bisa saja pelaksanaannya dilakukan arsitektur aplikasi terlebih dahulu. Adapun langkah-langkah yang dilakukan pada tahapan ini meliputi:

- Membuat gap analysis arsitektur sistem: kondisi arsitektur sistem informasi saat ini, analisis penyelesaian dan target penyelesaiannya. Tahapan ini akan menghasilkan tabel gap analysis dari arsitektur informasi;

- Melakukan pemodelan arsitektur data yang meliputi: analisis class data yang muncul dari pemetaan bisnis proses yang akan digunakan dalam arsitektur enterprise. Hasil dari tahapan ini berupa diagram class beserta relasinya yang digambarkan menggunakan class diagram.

- Melakukan pemodelan arsitektur aplikasi yang meliputi: melakukan analisis dana pengelompokan sistem informasi dan calon aplikasi yang dibutuhkan dalam sistem, arsitektur aplikasi ini didapat dari pemodelan arsitektur bisnis dan hasilnya merupakan sistem informasi dari aplikasi yang direkomendasikan. Pada tahapan ini akan menghasilkan portofolio aplikasi yang diajukan dalam bentuk tabel selanjutnya dan kemudian dibuatkan model hubungan proses/fungsi bisnis pada sistem dengan menggunakan use case diagram.

\section{Pemodelan Arsitektur Teknologi}

Tahapan ini dilakukan pemodelan arsitektur teknologi yang akan mendukung arsitektur dan mungkin untuk keseluruhan proses bisnis di SMK Negeri 1 Majalengka untuk masa yang akan datang. Adapun langkah-langkah yang dilakukan dalam tahapan ini meliputi:

- Membuat gap analysis teknologi: kondisi arsitektur teknologi saat ini, analisis penyelesaiaan dan target penyelesaiannya; 
- Melakukan pemodelan target arsitektur infrastruktur dan jaringan komputer masa depan;

- Pemodelan teknologi server dan piranti data center: menetapkan teknologi server dan data center yang akan mendukung proses pemodelan arsitektur;

- Pemodelan teknologi database: menetapkan teknologi database, DBMS (Database Management system) yang akan digunakan dalam mendukung pemodelan arsitektur sistem;

- Pemodelan teknologi software platform architecture untuk end user. Hasil dari tahapan ini berupa network computing diagram pada saat ini dan untuk masa depan jika ada perubahan, menentukan kandidat platform aplikasi, DBMS yang akan dipakai dalam bentuk dokumen pengajuan kepada pemangku keputusan.

\section{Peluang dan Solusi}

Kegiatan yang dilakukan dalam tahapan ini meliputi evaluasi, memilih alternatif implementasi, mendefinisikan strategi implementasi dan rencana implementasi. Hasil dari tahapan ini berupa dokumen permasalahan yang akan dihadapi serta alternatif solusi yang bisa menjadi pilihan bagi organisasi sebelum menerapkan hasil dari perencanaan yang diajukan sebelumnya. Pada penelitian ini, tidak semua tahapan Togaf ADM dilakukan. Tahapan Migration Planning, Implementation Governance dan Architecture Change Management tidak dibahas pada penelitian ini.

\section{HASIL DAN PEMBAHASAN}

\section{a) Diagram Proses Bisnis}

Pada tahapan ini yaitu pembuatan diagram dari hasil penelitian arsitektur bisnis yang ada pada SMKN 1 Majalengka dan kemudian dimodelkan menggunakan diagram bisnis BPMN (Business Process Model and Notation).

\section{1) Diagram BPMN PPDB ( Business Process Model and Notation Penerimaan Peserta Didik Baru)}

Proses ini berfokus pada pengelolaan PPDB (Penerimaan Peserta Didik Baru) dari perencanaan PPDB, promosi PPDB, sampai calon peserta didik baru melakukan daftar ulang. Hasil pengelompokan aktifitas-aktifitas dari proses PPDB( Penerimaan Peserta Didik Baru) dimodelkan menggunakan diagram BMPN(Business Process Model and Notation), dapat dilihat pada gambar dibawah ini:

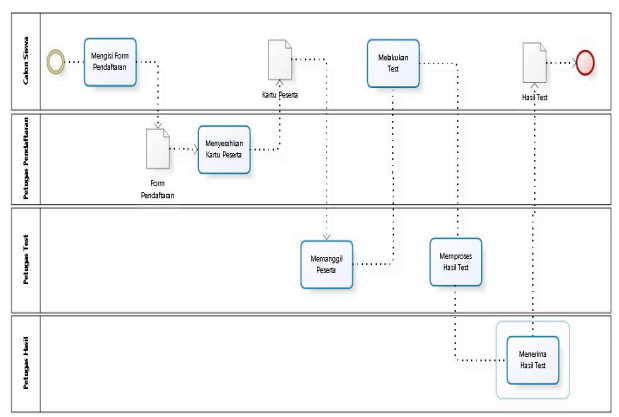

Gambar 2. Diagram BPMN PPDB

2) Diagram BPMN (Business Process Model and Notation) Pemerintahan Pendidikan 
Proses ini berfokus pada pengelolaan penyelenggaraan pendidikan yang menjadi aktivitas paling utama di SMKN 1 Majalengka, proses ini sebagian besar dipegang oleh bagian administrasi akademik (bidang kurikulum). Hasil pengelompokan aktivitas-aktivitas dari proses penyelengaraan pendidikan ini dimodelkan menggunakan diagram BPMN (Business Process Model and Notation), dapat dilihat pada gambar dibawah ini yaitu:

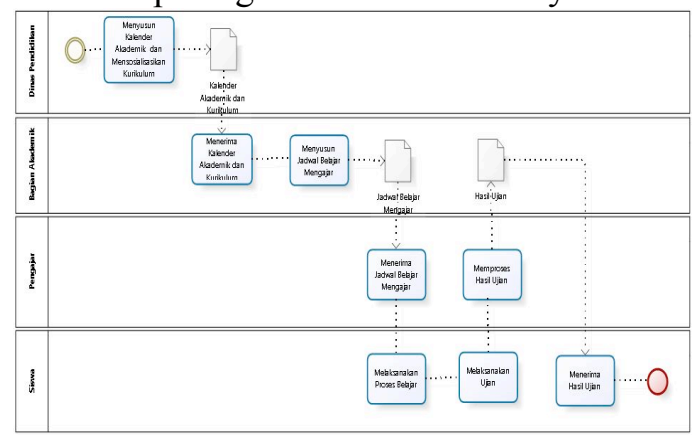

Gambar 3. Diagram BPMN Pemerintahan Pendidikan

\section{3) Diagram BPMN (Business Process Model and Notation) Perpisahan}

Proses ini merupakan proses aktivitas akhir pada proses belajar mengajar sebagai akhir dari studi siswa/siswi. Hasil pengelompokan aktivitas-aktivitas dari proses perpisahan dan dimodelkan menggunakan diagram BPMN (Business Process Model and Notation), dapat dilihat pada gambar dibawah ini yaitu:

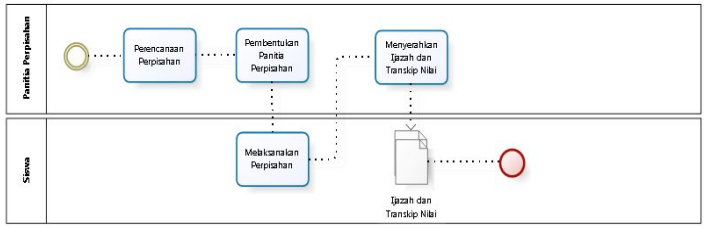

Gambar 4.Diagram BPMN Perpisahan

\section{4) Diagram BPMN(Business Process Model and Notation) Alumni dan Karir}

Proses ini merupakan pengelolaan alumni pada sekolah, dimulai dari pendataan alumnialumni, dan masih banyak yang lainnya. Berikut aktivitasaktivitas dari proses alumni dan pusat karir yang dimodelkan menggunakan diagram BPMN, dapat dilihat pada gambar dibawah ini yaitu:

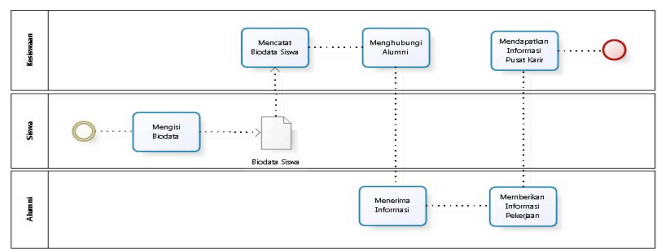

b) Class Diagram

Gambar 5. Diagram BPMN Alumni dan Karir

Pada tahapan ini yaitu pembuatan diagram dari hasil penelitian yang dilakukan di SMKN 1 Majalengka dan kemudian dimodelkan menggunakan class diagram. Clas diagram yaitu menggambarkan relasi antar data dan entitas yang ada dalam sistem informasi proses bisnis yang berkaitan dengan proses PPDB (Penerimaan Peserta Didik Baru), proses KBM (Kegiatan Belajar Mengajar), dll. 


\section{c) Kandidat Aplikasi}

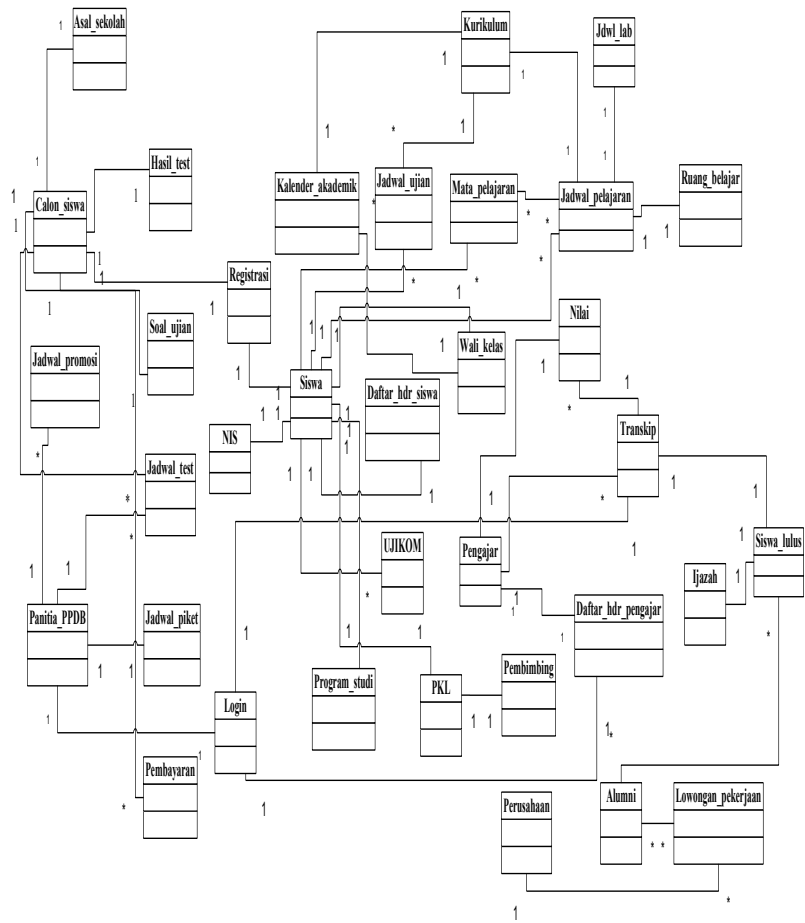

Gambar 6. Class Diagram Arsitektur Data

Berdasarkan pemetaan bisnis proses, maka didapat kebutuhan sistem informasi sebagai penunjang aktifitas bisnis utama untuk perencanaan arsitektur enterprise pada SMKN 1 Majalengka, berikut sistem informasi dan kandidat aplikasi yang dibutuhkan.

Berikut sistem informasi dan kandidat aplikasi yang dibutuhkan oleh sistem.

1) Sistem Informasi PPDB (Penerimaan Peserta Didik Baru)

Sistem informasi ini dibutuhkan untuk mengelola informasi-informasi mengenai penerimaan peserta didik baru. Aplikasi-aplikasi yang akan menjadi bagian dari sistem informasi penerimaan peserta didik baru dapat dilihat pada tabel 7.

Tabel 2. Kandidat aplikasi sistem informasi ppdb

\begin{tabular}{|l|l|}
\hline NO & \multicolumn{1}{|c|}{ Nama Aplikasi } \\
\hline 1 & $\begin{array}{l}\text { Aplikasi Pendaftaran Peserta Didik } \\
\text { Baru }\end{array}$ \\
\hline 2 & $\begin{array}{l}\text { Aplikasi Pengelolaan dan } \\
\text { Penjadwalan Test Masuk }\end{array}$ \\
\hline 3 & Aplikasi Ujian Test Masuk \\
\hline 4 & Aplikasi Pelaporan Peserta Didik Baru \\
\hline
\end{tabular}

\section{2) Sistem Informasi Akademik}

Sistem informasi ini dibutuhkan untuk mengelola informasi-informasi mengenai proses akademik. Aplikasi-aplikasi yang akan menjadi bagian dari sistem informasi akademik dapat dilihat pada tabel 8

Tabel 3. Kandidat aplikasi akademik

\begin{tabular}{|c|l|}
\hline NO & \multicolumn{1}{|c|}{ Nama Aplikasi } \\
\hline 1 & Aplikasi Perencanaan Oprasional Akademik \\
\hline 2 & Aplikasi Pengelolaan Siswa/i \\
\hline
\end{tabular}




\begin{tabular}{|l|l|}
\hline 3 & Aplikasi Pengelolaan Guru (pengajar) \\
\hline 4 & Aplikasi Penjadwalan KBM \\
\hline 5 & Aplikasi Hasil Studi \\
\hline 6 & Aplikasi E-Learning \\
\hline
\end{tabular}

\section{3) Sistem Informasi Perpisahan}

Sistem informasi ini dibtuhkan untuk mengelola informasi-informasi mengenai pelepasan akademik, pengelolaan status siswa/i dan pencetakan ijazah. Aplikasi-aplikasi yang akan menjadi bagian dari sistem informasi ini dapat dilihat pada tabel 9

Tabel 4. Kandidat aplikasi perpisahan

\begin{tabular}{|l|l|}
\hline NO & \multicolumn{1}{|c|}{ Nama Aplikasi } \\
\hline 1 & Aplikasi Data Siswa/i yang Lulus \\
\hline 2 & Aplikasi Transkip Nilai \\
\hline 3 & Aplikasi Pembuatan Ijazah \\
\hline
\end{tabular}

\section{4) Sistem Informasi Alumni}

Sistem ini dibutuhkan untuk mengelola informasi-informasi mengenai alumni dan lowongan pekerjaan sebagai media penyaluran alumni. Aplikasi- aplikasi yang akan menjadi bagian dari sistem informasi ini dapat dilihat pada tabel 10 .

\begin{tabular}{|c|c|}
\multicolumn{2}{|c}{ Tabel 5..Kandidat aplikasi alumni } \\
\hline NO & Nama Aplikasi \\
\hline 1 & Aplikasi Data Alumni \\
\hline 2 & Aplikasi Karir Alumni \\
\hline
\end{tabular}

d) Use Case Diagram SMKN 1 Majalengka

Use Case Diagram menggambarkan apa saja aktifitas yang dilakukan oleh suatu sistem dari sudut pandang pengamatan luar. Yang menjadi persoalan itu apa yang dilakukan bukan bagaimana melakukannya, maka berikut ini adalah hubungan mengenai sistem informasi pada SMKN 1 Majalengka digambarkan dengan use case diagram.

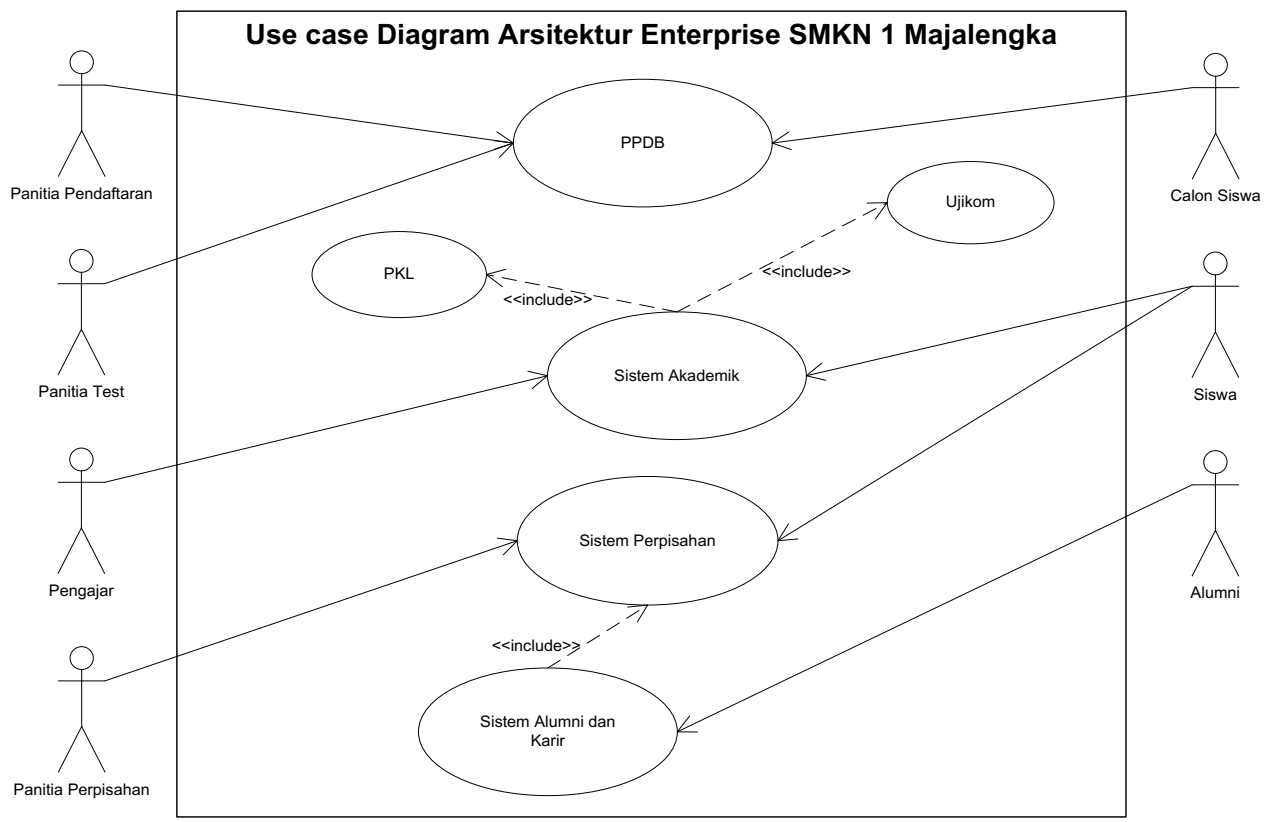


Gambar 7.Use Case Diagram

\section{e) Teknologi Saat Ini}

Pemetaan kondisi arsitektur teknologi saat ini diperlukan untuk melihat kondisi infrastruktur jaringan yang akan digunakan dalam perancangan model arsitektur dimasa mendatang. Apakah arsitektur jaringan komputer yang sekarang sudah memadai atau belum. Berikut merupakan hasil analisis kondisi arsitektur teknologi di SMKN 1 Majalengka:

- SMKN 1 Majalengka ini di dalam menjalankan proses bisnisnya kebanyakan masih manual tidak terkomputerisasi dan yang sudah terkomputerisasi belum semuanya terintegrasi ke sistem informasi;

- Saat ini SMKN 1 Majalengka jaringannya masih kurang memadai, yang diantaranya koneksi jaringannya masih lambat karena banyaknya pengguna yang mengakses jaringan tersebut.

\section{f) Teknologi Yang Diusulkan}

Apabila ada rekomendasi yang diusulkan yakni dengan mengganti perangkat yang sudah usang dengan yang baru, mengganti kabel dengan kabel UTP (Unshied Twisted Pais) Belden USA cat6, mengganti konektor nya dengan Belden cat6, mengganti switch dengan Tp-Link Gigabyte, meningkatkan kecepatan yang tadinya $100 \mathrm{Mbps}$, ditambah $100 \mathrm{Mbps}$ sehingga stabilitas data akan lebih terjaga, dan lebih stabil. Berikut beberapa perangkat yang harus di ganti sehingga kesetabilannya lebih terjaga, user dalam mengaksesnya tidak memakan waktu lama. Berikut beberapa perangkat yang diusulkan:

- Kabel UTP Belden USA Cat 6

Kabel jenis ini kualitasnya tidak usah diragukan lagi, urat kawatnya cukup bagus dengan diameter 0,573mm (23 AWG) American Wire Gauge (AWG) merupakan standarisasi yang telah digunakan sejak 1957 untuk kawat konduksi listrik. Untuk pemasangan konektornya juga akan sekali jadi.

- Konektor RJ45 Belden USA Cat 6

Kabelnya yang berkualitas otomatis konektor yang dipakai harus yang berkualitas juga dan tahan lama, konektor Rj45 Blend USA Cat6 yang dipilih sudah pasti kualitasnya jangan diragukan lagi, dan sudah pasti ketahannya.

- Switch Tp-Link Gigabyte

Switch ini dipilih karena kualitasnya yang tidak bisa diragukan lagi, selain kabel dan konektor yang berkualitas switchnya juga harus memilih yang sudah pasti kualitas dan ketahannya.

Dan arsitektur teknologi yang diusulkan dapat di simpulkan yaitu hanya sebuah usulan untuk mempermudah proses bisnis pada SMKN 1 Majalengka yang berada di Kabupaten Majalengka dalam menjalankan prosedur yang sesuai kurikulum terhadap siswa/i. Perencanaan arsitektur teknologi terdiri dari :

- Spesifikasi Teknologi Server yang digunakan dalam kegiatan operasional sehari-hari seharusnya terpisah dari aplikasi-aplikasi yang sedang dikembangkan dan harus memenuhi standard spesifikasi sebagaimana mestinya sebuah server;

- Sistem Operasi untuk server yang digunakan di usulkan memakai sistem operasi linux;

- Spesifikasi Database yang diusulkan adalah : MsSql Server / Mysql / PosgresSql sebagai database server;

- Spesifikasi perangkat lunak, perangkat keras dan topologi jaringan untuk client masih tetap menggunakan perangkat lunak, perangkat keras dan topologi yang sedang berjalan pada ruangan;

- Perlunya penataan ulang pada ruangan server di SMKN 1 Majalengka, sehingga ruangnnya jadi lebih tertata, terorganisir, rapih, dan enak dipandang; 


\section{- Browser (Internet Explorer, Google Chrome, Mozilla Firefox)}

\section{g) Peluang dan Solusi}

Peluang dan solusi dari pemodelan arsitektur yang di rancang sebelumnya bertujuan untuk menghasilkan sistem informasi sesuai target dalam perencanaan. Solusi yang dilakukan dalam usulan ini adalah melakukan perencanaan dan pengembangan aplikasi - aplikasi dan menyediakan infratuktur yang dibutuhkan. Berikut ini beberapa hal yang harus di perhatikan untuk memeperkecil resiko kegagalan.

1) Pertimbangan Ekonomis ( Biaya Implementasi )

Karena sistem ini akan diterapkan pada sekolah menengah kejuruan, maka anggaran pun harus disesuaikan dengan anggaran yang ada.

2) Pengembangan SDM ( Sumber Daya Manusia )

Sumber daya manusia ini berkaitan dengan bagian yang menangani dan menjalankan sistem ini. Yang diantaranya yaitu mengadakan pelatihan pada semua guru/pekerja di SMKN 1 Majalengka tentang penggunaan komputer dan penggunaan aplikasi-aplikasi yang akan dibuat di masa yang akan datang.

3) Mengurangi resiko saat pengembangan dan penerapan sistem dengan cara:

- Melakukan testing terhadap modul aplikasi yang akan diterapkan;

- Mendokumentasikan seluruh sistem informasi secara lengkap dan terstruktur sehingga apabila terdapat kesalahan dapat dengan mudah ditelusuri.

4) Rancangan anggaran biaya untuk penggantian piranti yang usang, jasa pembuatan aplikasi, dan jasa pembuatan sistem informasi pada SMKN 1 Majalengka seperti pada Tabel 11 Rancangan Anggaran Biaya.

Tabel 6. Rancangan anggaran biaya

\begin{tabular}{|l|l|l|l|l|l|}
\hline No & Item & Jumlah & Satuan & Harga & Total \\
\hline 1 & $\begin{array}{l}\text { UTP Belden USA } \\
\text { Cat6 }\end{array}$ & 13 & Roll & 1.500 .000 & 19.500 .000 \\
\hline 2 & $\begin{array}{l}\text { Connector RJ45Beldn } \\
\text { USACat6 }\end{array}$ & 3 & Box & 480.000 & 1.440 .000 \\
\hline 3 & $\begin{array}{l}\text { Switch TP-Link } \\
\text { Gigabyte 16 port } \\
1000 \text { MBps }\end{array}$ & 8 & Unit & 1.150 .000 & 9.200 .000 \\
\hline 4 & $\begin{array}{l}\text { Pembuatan Aplikasi } \\
\text { Informasi Sistem }\end{array}$ & 13 & Unit & 2.000 .000 & 26.000 .000 \\
\hline 5 & $\begin{array}{l}\text { Pembuatan Unit } \\
\text { In 3.000.000 }\end{array}$ & 3.000 .000 \\
\hline
\end{tabular}

\section{KESIMPULAN}

Berdasarkan hasil pembahasan yang telah disampaikan sesuai dengan tahapan penelitian yang mengacu pada aturan metode framework TOGAF, maka dapat diambil beberapa kesimpulan sebagai berikut :

- Dengan melakukan analisis ini telah dihasilkan sebuah blueprint perencanaan arsitektur enterprise yang mengacu pada konsep framework TOGAF yang meliputi arsitektur bisnis, data, aplikasi, dan teknologi guna menudukng aktifitas bisnis utama pada SMKN 1 Majalengka. 
- Analisis ini menghasilkan sebuah usulan perbaikan teknologi yang ada agar user dapat lebih cepat mengakses sistem dan menghasilkan sebuah sistem yang mengintergrasikan seluruh unit di SMKN 1 Majalengka.

\section{DAFTAR PUSTAKA}

[1] Atina Dwi Palupi. 2006. Aplikasi Penjualan On-line Untuk Mendukung Perdagangan Lokal Berbasis Web Pada CV. Rabbani Muslimah. Tugas Akhir. Bandung: Universitas Telkom

[2] Armanda, R. A. 2010. Teknologi Cloud Computing Menggunakan Cloudsim untuk Implementasi Konsep TIK Hijau. 4-9.

[3] Edi Surya Negara dan Yanti Febri. 2016.Pengembangan Model Arsitektur Teknologi Informasi Berbasis Cloud Computing Untuk Institusi Perguruan Tinggi di Sumatera Selatan. Jurnal Teknologi Technoscientia, Vol.8 No.2 , Feb 2016, ISSN: 1979-8415

[4] Henry Lucas, Jr. (2007). Analisis, Desain dan Implementasi Sistem Informasi, Penerbit Erlangga.

[5] Iyan Supriyana. 2010. Model Arsitektur Bisnis, Sistem Informasi dan Teknologi di Bakosurtanal Berbasis Togaf. Jurnal Telkomnika Volume.8 No.1 : 17-24

[6] M. Zain Muttaqien, Eka Kusmayadi,(2008). Dasar- Dasar Teknologi Informasi, Penerbit Universitas Terbuka.

[7] Mardiansyah, C. R. (2012). Analisis dan Pengembangan Enterprise Arsitektur Menggunakan Framework TOGAF pada Pengadilan Agama Bandung 7-20

[8] Nugroho, S. J. (2012). Enterprise Architecture Planning Sistem Informasi RSIA ANDINI dengan Menggunakan TOGAF.

[9] Nurma Harumiaty, Eva Hariyanti, Taufik. 2013.Perencanaan Arsitektur Teknologi Informasi Studi Kasus Pada Perpustakaan Universitas Airlangga. Jurnal Sistem Informasi Volume 1 No.1

[10] Rahardjo, B. (2006). Memahami Teknologi Informasi. Jakarta: PT. Elex Media Komputindo

[11] Rahman Rosyidi, Purwadi. 2014. Perancangan Pengembangan Arsitektur Sistem Informasi Akademik dengan Menggunakan Togaf (Studi Kasus STMIK Amikom Purwokerto). Jurnal Telematika, Volume.7, No.1

[12] Ridwan Setiawan, S.M.(2014). Perancangan Arsitektur Enterprise E-STTG Menggunakan Togaf ADM (Studi Kasus Di STT Garut). 6-7.

[13] Roni Yunis, T. Kridanto Surendro . 2009. Perancangan Model Enterprise Architecture dengan Togaf Architecture Development Method. Seminar Nasional Aplikasi Teknologi Informasi Yogyakarta. ISSN: 1907-5022

[14] Setiawan, R.(2014). Perancangan Arsitektur Enterprise E-STTG Menggunakan Togaf ADM (Studi Kasus Di STT Garut). 6-7.

[15] Slamet Riyadi,B.S. (2015). Pemodelan Enterprise Architecture Pelayanan di RSUD Murjani Sampit. 316-328.

[16] Widiyanto Hadi, Abidarin Rosidi, Emha Lutfi. 2013. Analisis Pemodelan Arsitektur Enterprise Untuk Mendukung Sistem Informasi Akademik dengan Togaf ( Studi Kasus AMIK AMIKOM Surakarta). Duta.com. ISSN: 2086-9436. Vol. 5, No. 1.

[17] Yeni Kustiyaningsih. 2013. Perencanaan Arsitektur Enterprise Menggunakan Metode Togaf ADM (Studi Kasus RSUD Dr. Soegiri Lamongan). ISBN :978-602-97491-7-5, C-17-1 